\title{
Combination of solarization, biofumigation and grafting techniques for the management of bacterial wilt in tomato
}

\author{
André R Zeist ${ }^{1,3} \mathbb{D}$; Juliano TV de Resende ${ }^{2,4} \mathbb{D}$; Bruna C Pozzebon ${ }^{3} \mathbb{D}$; André Gabriel ${ }^{4} \mathbb{D}$; Alex Antônio da \\ Silva ${ }^{4} \mathbb{D}$; Ricardo Antônio Zeist ${ }^{4} \mathbb{D}$
}

${ }^{1}$ Universidade do Oeste Paulista (UNOESTE), Presidente Prudente-SP, Brasil; andrezeist@ unoeste.br; ${ }^{2}$ Universidade Estadual de Londrina (UEL), Londrina-PR, Brasil; jvresende@uol.com.br; ${ }^{3}$ Universidade Federal de Lavras (UFLA), Lavras-MG, Brasil; bcpozzebon@gmail. com; ${ }^{4}$ Universidade Estadual do Centro-Oeste (UNICENTRO), Guarapuava-PR, Brasil; andre.gb85@hotmail.com; alex.antonio.silva27@ gmail.com; ricardo-zeist@bol.com.br

\begin{abstract}
Considering the aforementioned information, the objective was to evaluate the influence of combining techniques of solarization, biofumigation with chicken manure and grafting on the incidence of bacterial wilt and productivity of the hybrid tomato 'Absoluto'. Two experiments were carried out in a chapel-type greenhouse and in field, in the agricultural year 2013/2014, in a commercial farm on the municipality of Barra do Rio Azul-RS. In the two cultivation environments, treatments were arranged in randomized block experimental design, with the plots subdivided into space and treatments randomly arranged, in an area naturally infested with race 1, biovar 1, phylotype II of $R$. solanacearum. The treatments were soil solarization, biofumigation, biofumigation + solarization and control, and in the subplots, the commercial hybrid tomato Absoluto with and without grafting on the hybrid rootstock Guardião. Based on the incidence of bacterial wilt, the plant health index and the area under the disease progress curve were estimated. The number, production and average mass of commercial fruits were evaluated. A beneficial effect was found of soil solarization associated with the addition of chicken manure in the control of bacterial wilt and increase of productivity. Grafting was more efficient in increasing plant health index and reducing the area under the disease progress curve than solarization and biofumigation, thus indicating that the association of the three measures is beneficial to the integrated control of the disease.
\end{abstract}

Keywords: Solanum lycopersicum, Ralstonia solanacearum, soil pathogens control, soil disinfestation, rootstock.

\section{RESUMO}

Combinação das técnicas de solarização, biofumigação e enxertia para o manejo da murcha bacteriana no tomateiro

Objetivou-se avaliar o efeito da combinação das técnicas de solarização, biofumigação com cama de frango e enxertia na incidência da murcha bacteriana e na produtividade do tomateiro híbrido Absoluto. Foram realizados dois experimentos, em casa de vegetação tipo capela e em campo, no ano agrícola 2013/2014, em propriedade agrícola no município de Barra do Rio Azul-RS. Nos dois ambientes de cultivo, os tratamentos foram organizados em delineamento experimental de blocos casualizados, com as parcelas subdivididas no espaço e os tratamentos dispostos aleatoriamente, em área naturalmente infestada com Ralstonia solanacearum raça 1, biovar 1, filotipo II. Os tratamentos nas parcelas foram solo com solarização, biofumigação, solarização + biofumigação e testemunha; nas subparcelas, foi usado o tomateiro híbrido comercial Absoluto com e sem enxertia sobre o porta-enxerto híbrido comercial Guardião. Com base na incidência da murcha bacteriana, estimou-se o índice de sanidade e a área abaixo da curva de progresso da doença. Avaliou-se também o número, a produção e a massa média de frutos comerciais. Foi constatado efeito benéfico da solarização do solo associada à biofumigação no controle da murcha bacteriana e aumento da produtividade. A enxertia foi mais eficiente no aumento do índice de sanidade e redução da área abaixo da curva de progresso da doença que a solarização e biofumigação, indicando que a associação dos tratamentos é eficaz no controle da doença.

Palavras-chave: Solanum lycopersicum, Ralstonia solanacearum, controle de patógenos do solo, desinfestação do solo, porta-enxerto.

Received on January 25, 2018; accepted on May 16, 2019

A mong the main factors that affect tomato productivity in Brazil, diseases of bacterial etiology, which are difficult to handle and control, stand out. Amidst them, bacterial wilt stands out, caused by the complex of soildwelling species of the genus Ralstonia, formed by $R$. solanacearum and $R$. pseudosolanacearum (Fegan \& Prior, 2005; Lopes, 2015). Initial symptoms are wilt of the terminal leaves, darkening of the vascular region, wilt leaflet and leaf epinasty. With the progression of the disease, wilt affects the whole plant irreversibly, and the plant dies (InoueNagata et al., 2016).
Bacterial wilt is a disease of difficult control, especially in climates subject to high temperatures, due to its global distribution, high genetic variability, long-term survival of the pathogen in soil and a wide range of hosts (Lebeau et al., 2011; Lopes, 2015). Although these characteristics indicate that individual 
measures of control of bacterial wilt are not effective, studies that propose to integrate different management methods in the control of the disease are scarce (Baptista et al., 2007; Oz et al., 2017). Among these, we should appeal to those with a greater focus on environmental issues and that are not detrimental to the health of farmers and consumers (Baptista et al., 2007).

Solarization is an efficient method to control soil pathogens and reduce the use of agrochemicals (Kanaan et al., 2016; Oz et al., 2017). This method is based on the use of solar energy to raise soil temperature by 10 to $15^{\circ} \mathrm{C}$ and affect the survival of the pathogen at depths of approximately $20 \mathrm{~cm}$ (Kanaan et al., 2015).

Alternatively, there could be the addition of compounds that alter the microbial activity and affect survival of pathogens (Kanaan et al., 2015, 2016). Using organic biofumigants, besides increasing soil fertility, is effective in controlling soil diseases (Oz et al., 2017). The biofumigant effect by the addition of chicken manure to the soil has already been described in some works carried out in Brazil (Baptista et al., 2006, 2007; Coca et al., 2012). Solarization for four months or biofumigation at $5 \%$ with chicken manure in a tropical climate region, in Brasilia-DF, reduced the incidence of $R$. solanacearum in potatoes and tomatoes (Baptista et al., 2006; Coca et al., 2012).

Tomato grafting in resistant rootstock is an alternative increasingly used for the control of bacterial wilt (Lopes et al., 2015). This technique, even in Brazil, is more widespread than solarization and biofumigation. Protection provided solely by grafting, however, should be considered with certain restrictions, since it may not work properly in the presence of isolates that "break" the resistance and in situations of environments favorable to the disease, such as in the Amazon region (Lopes, 2015; Lopes et al., 2015).

There are few studies on the efficacy of the combination of these techniques in the control of bacterial wilt and its influence on productive output of the tomato plant. In addition, there is a need to observe the effectiveness of this combination in different growing environments and in subtropical climates, considering the pathogen population in the soil, its specific virulence in the isolates in the region, the local efficiency of solarization in certain times of the year and chemical and biological composition of the soil.

Considering the aforementioned information, the objective was to evaluate the influence of combining techniques of solarization, biofumigation with chicken manure and grafting for the bacterial wilt and productivity of the hybrid tomato Absoluto in two commercial growing environments, in Barra do Rio Azul-RS.

\section{MATERIAL AND METHODS}

Two experiments were carried out in a chapel-type greenhouse (protected environment) and in field (external), from June to February in the agricultural year $2013 / 2014$, at a property in the municipality of Barra do Rio Azul-RS $\left(27^{\circ} 24^{\prime} \mathrm{S}, 52^{\circ} 26^{\prime} \mathrm{W}\right.$, altitude $438 \mathrm{~m}$ ). The municipality belongs to the northwest mesoregion of Rio Grande do Sul and to the micro-region of Erechim-RS and, according to Köppen's climatic classification, it presents a subtropical humid climate (Wrege et al., 2011). The site soil is classified as Red Latosol.

In both cultivation environments, the treatments were arranged in randomized block experimental design, with the plots subdivided into space and treatments randomly arranged, in an area naturally infested with race 1 , biovar 1, phylotype II of $R$. solanacearum. Treatments in the plots were soil with solarization, biofumigation, solarization + biofumigation, and control (absence of treatments) and, in the subplots, the hybrid commercial tomato Absoluto (Feltrin) ungrafted (without rootstock) and grafted on the commercial hybrid rootstock Guardião (Takii). The hybrid Absoluto has a habit of semi-determined growth, produces salad type fruits and is susceptible to bacterial wilt. The rootstock 'Guardião' is resistant to bacterial wilt and is available in the Brazilian market (Lopes et al., 2015).

The experiments in greenhouse and in the fields were in areas that had already a continuous cultivation of tomato plants. In these areas, in the five years prior to the implantation of the experiments, the presence of wilt symptoms caused by $R$. solanacearum was confirmed. In the greenhouse experiment, plots were $3.0 \times 6.0 \mathrm{~m}$ and subplots $3.0 \times 3.0 \mathrm{~m}$ and the 18 central plants of each subplot were considered as useful area. In the field environment, plots were $4.0 \times 12 \mathrm{~m}$ and the subplots $4.0 \times 6.0 \mathrm{~m}$ and the 30 central plants of each subplot were considered as useful area.

Before the application of the treatments in the plot, the soil of both environments was revolved up to $20 \mathrm{~cm}$ deep. The application of the treatments was succeeded according to Baptista et al. (2007), in which, for four months (from June to September) before transplanting the seedlings, solarization and biofumigation were carried out by means of transparent polyethylene plastic covering, $75 \mu \mathrm{m}$ thickness, and incorporation of chicken manure to the soil in $5 \%(\mathrm{v} / \mathrm{v})$ concentration, respectively.

In a greenhouse, which had a $3.0 \mathrm{~m}$ ceiling height, during this period the side curtains were kept closed and weekly irrigation was carried out by sprinkling to the field capacity. Treatments with solarization were irrigated only before the installation of the transparent polyethylene plastic cover. During the solarization and biofumigation period, the soil temperature data were collected at $10 \mathrm{~cm}$ depth every 15 days, at 12:30 hs, by using a stick digital thermometer (TP3001, Digital Thermometer).

At the beginning October, the polyethylene was removed and, in all plots, ungrafted and grafted seedlings were transplanted, when they had from 4-5 expanded defined leaves. The adopted spacings were $1.0 \mathrm{~m}$ between rows and 0.45 between plants in the greenhouse and $1.0 \mathrm{~m}$ between rows and $0.6 \mathrm{~m}$ between plants in the field. Plants were conducted by maintaining a main stem and supported by vertical cutting.

During the cycle, for irrigation, in both experiments, micro drippers were used, with the application of fertirrigation in the morning, following recommendations adapted from 
Trani et al. (2011), depending on the development stage of the crop. Phosphorus(P) was supplied only in transplanting, at the dose of $70.0 \mathrm{~g}$ of single superphosphate (SSP) per $\mathrm{m}^{2}$, according to the previously performed soil analysis.

For the formulation of fertigation, $0.015 \mathrm{~g}$ urea, $0.06 \mathrm{~g}$ potassium chloride, $0.012 \mathrm{~g}$ Nitrabor, $0.03 \mathrm{~g}$ Krista SOP and 0.1 Krista Mag per plant were used in the first phase. In the second phase, 0.11 g potassium chloride, $0.05 \mathrm{~g}$ Nitrabor, $0.1 \mathrm{~g}$ Krista SOP and 0.4 Krista Mag per plant were used. In the third phase, 0.17 $\mathrm{g}$ potassium chloride, $0.24 \mathrm{~g}$ Nitrabor, 0.4 g Krista SOP and 0.87 g Krista Mag were used per plant. In the fourth phase, $0.17 \mathrm{~g}$ potassium chloride, 0.48 g Nitrabor, 0.4 g Krista SOP and 1.1 Krista Mag per plant were used, and in the fifth phase, $0.2 \mathrm{~g}$ potassium chloride, 0.48 g Nitrabor, 0.4 g Krista SOP and $1.1 \mathrm{~g}$ Krista Mag were used per plant.

The incidence of bacterial wilt was evaluated from 14 days after transplanting, and performed every 15 days, until 84 days after transplanting, totalizing six evaluations. Plants showing symptoms of wilt were recorded, in which those with partial wilt ( $\geq 50 \%$ wilted leaves) or total wilt were considered for evaluation. According to Lopes \& Rossato (2013), in order to confirm the infection of plants by $R$. solanacearum, the lower part of the stem was submerged in a clear vial containing water and the presence of a milky fillet was identified outlying the tissue of the wilting plants. The resistance characteristics of the plant to the pathogen were estimated by calculating the plant health index (PHI) and the area under the disease progress curve (AUDPC). PHI values were estimated using the formula: PHI $=\mathrm{NP} / \mathrm{TNT}$, where NP is the number of plants in the plot with no symptoms of wilt in the last evaluation and TNT is the total number of plants in the plot (Plank, 1963). The area under the disease progress curve (AUDPC) was calculated according to Campbell \& Madden (1990).

Fruits were harvested according to Zeist et al. (2017b), during which the fruits that comprised the light-red maturation stage were collected during the cycle, which were then evaluated by: 1) the number of commercial fruits (NCF), determined by the sum of the number of harvested fruits, in order to establish the total number of fruits classified within the commercial standards per plant; 2) production of commercial fruits (PCF, kg/plant), determined by weighing the cumulative production of fruits in order to establish the total production of fruits classified within the commercial standards per plant; and 3) average mass of commercial fruits (AMCF, $g$ /fruit), determined based on the relationship between $\mathrm{PCF}$ and $\mathrm{NCF}(\mathrm{AMCF}=\mathrm{PCF} / \mathrm{NCF})$.

Data of the evaluated characteristics were tested for normality and homogeneity of the residual variances by Lilliefors \& Bartlett tests, respectively, and later submitted to analysis of variance. When $\mathrm{F}$ test was significant, averages were compared by Tukey test $(p \leq 0.05)$, and analyzed in the statistical program ASSISTAT, version 7.7 (Silva \& Azevedo, 2016).

\section{RESULTS AND DISCUSSION}

In both cultivation environments, at $10 \mathrm{~cm}$ depth, in the soil that was solarized, higher temperatures were observed than those of the other treatments (Table 1). The soil of the greenhouse, during the months August and September, presented temperatures above $50^{\circ} \mathrm{C}$ and with averages approximately $10^{\circ} \mathrm{C}$ above the treatments without solarization. In the field environment, although average soil temperatures were lower than those in the greenhouse, solarization also provided an increase in temperature. We observed in the soil of this environment, in September, temperatures near $49^{\circ} \mathrm{C}$ and with average approximately $12^{\circ} \mathrm{C}$ above the treatments without solarization (Table 1).

Higher soil temperatures in September, when compared to the months June to September, happened due to air temperature in the region of the experiment be lower in the first three months of follow-up. In the solarization carried out in the field, in Brasília-DF, where the climate is characterized as tropical, Baptista et al.
(2007) observed throughout the period soil temperatures around $50^{\circ} \mathrm{C}$ and about $10^{\circ} \mathrm{C}$ above the non-solarized soil. In contrast, in experiments conducted in Inparta, Turkey, where air temperature conditions are similar to the region of this work, Oz et al. (2017) verified, during the solarization period in the greenhouse, a soil temperature variation similar to those described in Table 1. It is reported that heat treatment at $45^{\circ} \mathrm{C}$ for two days, under controlled conditions, is enough to reduce the total bacterial population by $60-97 \%$ and the incidence of bacterial wilt by $50-75 \%$ (Yuliar \& Toyota, 2015).

As in this work, Kanaan et al. (2016) observed a rise in soil temperature by about $12^{\circ} \mathrm{C}$ when solarized and no significant increase in temperature with the application of organic additives. Similar results were also observed by Kanaan et al. (2015) by studying the effects of solarization and the application of organic compounds in soils infested with Macrophomina phaseolina and Verticillium dahliae.

For the characteristics related to the control of bacterial wilt, there was interaction between treatments of plots and subplots in the greenhouse and field crops. When grafting, there was no effect of the treatments applied to the soil. In contrast, when hybrid Absoluto plant was cultivated on an ungrafted basis in both growing environments, the treatments compared to the control resulted in increased plant health index and reduced AUDPC (Table 2). Baptista et al. (2007), with same solarization period and same chicken manure concentration of this study, also observed reduction in the number of plants affected by bacterial wilt. However, these authors did not observe interaction between solarization and biofumigation.

In both growing environments, grafting of the hybrid Absoluto on the rootstock 'Guardião', compared to the same ungrafted plants, increased health and reduced disease progression, except when grafted plants were cultivated in the greenhouse and the soil received solarization + biofumigation (Table 2). Lopes et al. (2015) observed that 'Guardião' offers good protection to 
Table 1. Effects of solarization and biofumigation with chicken manure in soil naturally infested with Ralstonia solanacearum on soil temperature $\left({ }^{\circ} \mathrm{C}\right), 10 \mathrm{~cm}$ depth, during the observation period in two growing environments. Barra do Rio Azul, UNICENTRO, $2013 / 2014$.

\section{Greenhouse}

\begin{tabular}{|c|c|c|c|c|c|c|c|c|c|c|c|c|}
\hline \multirow{2}{*}{ Treatments } & \multicolumn{3}{|c|}{ Biofumigation } & \multicolumn{3}{|c|}{ Solarization } & \multicolumn{3}{|c|}{$\mathbf{B}+\mathbf{S}^{1}$} & \multicolumn{3}{|c|}{ Control } \\
\hline & $\operatorname{Max}$ & Min & Avg & Max & Min & Avg & $\operatorname{Max}$ & Min & Avg & Max & Min & Avg \\
\hline June & 35.5 & 15.3 & 24.8 & 41.5 & 17.2 & 34.5 & 41.4 & 17.7 & 34.4 & 35.5 & 13.2 & 24.1 \\
\hline July & 35.5 & 13.7 & 25.5 & 44.4 & 16.9 & 34.6 & 44.4 & 17.0 & 34.5 & 35.0 & 11.6 & 25.4 \\
\hline August & 37.1 & 15.9 & 27.8 & 51.2 & 21.2 & 37.4 & 52.0 & 25.0 & 37.3 & 37.0 & 13.6 & 28.1 \\
\hline September & 37.9 & 23.9 & 28.5 & 52.0 & 28.5 & 39.3 & 53.0 & 29.1 & 39.8 & 38.1 & 22.1 & 28.9 \\
\hline & \multicolumn{12}{|c|}{ Field } \\
\hline June & 29.6 & 10.3 & 18.9 & 38.1 & 11.7 & 26.2 & 38.1 & 12.0 & 26.3 & 29.6 & 10.3 & 18.9 \\
\hline July & 30.3 & 9.9 & 19.1 & 38.6 & 10.4 & 26.3 & 38.4 & 10.5 & 26.4 & 29.9 & 9.6 & 19.1 \\
\hline August & 30.6 & 10.8 & 22.1 & 42.0 & 20.8 & 33.7 & 41.9 & 23.3 & 33.4 & 30.5 & 10.8 & 22.0 \\
\hline September & 33.5 & 18.2 & 26.4 & 48.7 & 22.8 & 38.5 & 48.9 & 24.2 & 39.2 & 33.9 & 17.9 & 25.1 \\
\hline
\end{tabular}

${ }^{1} \mathrm{~B}+\mathrm{S}=$ biofumigation + solarization; $\mathrm{Max}=$ maximum temperature; Min= minimum temperature; Avg= average temperature.

Table 2. Effects of solarization and biofumigation with chicken manure in soil naturally infested with Ralstonia solanacearum on plant health index (PHI) and area under the disease progress curve (AUDPC) of hybrid tomato Absoluto, grafted and ungrafted on the commercial hybrid rootstock Guardião in two growing environments. Barra do Rio Azul, UNICENTRO, 2013/2014.

\begin{tabular}{|c|c|c|c|c|}
\hline \multirow{3}{*}{ Treatments } & \multicolumn{3}{|c|}{ Greenhouse } & \\
\hline & & & \multicolumn{2}{|c|}{ AUDPC } \\
\hline & Grafted & Ungrafted & Grafted & Ungrafted \\
\hline Solarization & $0.97 \mathrm{Aa}^{*}$ & $0.77 \mathrm{Bb}$ & $8.75 \mathrm{Ba}$ & $77.00 \mathrm{Ab}$ \\
\hline Biofumigation & $0.97 \mathrm{Aa}$ & $0.82 \mathrm{Ba}$ & $8.75 \mathrm{Ba}$ & $70.00 \mathrm{Ab}$ \\
\hline Solarization + biofumigation & $0.95 \mathrm{Aa}$ & $0.92 \mathrm{Aa}$ & $10.50 \mathrm{Aa}$ & $26.25 \mathrm{Ac}$ \\
\hline Control & $0.97 \mathrm{Aa}$ & $0.45 \mathrm{Bb}$ & $8.75 \mathrm{Ba}$ & $224.00 \mathrm{Aa}$ \\
\hline \multirow[t]{2}{*}{$\mathrm{CV}(\%)$} & \multicolumn{2}{|c|}{10.15} & \multicolumn{2}{|c|}{42.03} \\
\hline & \multicolumn{3}{|c|}{ Field } & \\
\hline Solarization & $0.95 \mathrm{Aa}$ & $0.67 \mathrm{Ba}$ & $21.00 \mathrm{Ba}$ & $154.00 \mathrm{Ab}$ \\
\hline Biofumigation & $0.92 \mathrm{Aa}$ & $0.45 \mathrm{Bab}$ & $29.75 \mathrm{Ba}$ & $248.50 \mathrm{Aab}$ \\
\hline Solarization + biofumigation & $0.92 \mathrm{Aa}$ & $0.67 \mathrm{Ba}$ & $38.50 \mathrm{Ba}$ & $148.75 \mathrm{Ab}$ \\
\hline Control & $0.95 \mathrm{Aa}$ & $0.22 \mathrm{Bb}$ & $21.00 \mathrm{Ba}$ & $355.25 \mathrm{Aa}$ \\
\hline $\mathrm{CV}(\%)$ & \multicolumn{2}{|c|}{17.92} & \multicolumn{2}{|c|}{49.95} \\
\hline
\end{tabular}

* Means followed by same lowercase letters in the column and same uppercase letters in the line, do not differ significantly from each other by Tukey test, $\mathrm{p} \leq 0.05 ;{ }^{1} \mathrm{PHI}=\mathrm{NP} / \mathrm{TNT} ; \mathrm{NP}=$ number of plants without wilt symptoms in the last evaluation; TNT $=$ total number of plants (Plank, 1963).

the tomato against bacterial wilt under normal growing conditions. According to these authors, this rootstock also shows resistance to fusarium wilt (some races), verticillium wilt and some species of nematodes of the genus Meloidogyne.

In the greenhouse environment for ungrafted plants, treatments with biofumigation were the most efficient in increasing plant health index and the combination of solarization + biofumigation was the one that reduced AUDPC values the most (Table 3).
The effect of adding poultry litter for disease reduction is possibly related to the effects of decomposition of the material on soil microbial activity. The organic changes in the soil increase the probability of competition effects caused by the increase of the activities of microorganisms that are antagonistic to the pathogen (Yuliar \& Toyota, 2015). In addition, degradation of organic matter may restrict the available nutrients to the pathogen and release natural substances with variable inhibitory properties (Bailey \& Lazarovitz, 2003;
Mehta et al., 2014). The decomposition of chicken manure releases volatile nitrogen compounds (Silva et al., 2014), which leads to possible toxic effects on R. solanacearum (Baptista et al., 2006; Coca et al., 2012).

About solarization, despite reducing soil $\mathrm{pH}$ and the concentration of potassium, sodium, boron and zinc nutrients, it decreased biomass and microbial respiration, with subsequent increase in respiration, 60 days after solarization (Baptista et al., 2007). The combination of this technique with 
biofumigation was more efficient than isolated solarization or biofumigation, negatively affecting bacterial wilt. In addition, in the greenhouse cultivation, solarization + biofumigation proved to be as efficient as the use of grafting using the 'Guardião' rootstock. In this environment, with solarization + biofumigation, there was no difference between grafted and ungrafted plants for the characteristics related to controlling bacterial wilt (Table 2). Solarization in the presence of organic additives may accelerate the emission of toxic volatiles that stimulate the predation or suppression of reproductive organs of soil pathogens (Kanaan et al., 2015).

It is important to emphasize that soil temperature elevations promoted by solarization technique may have a limited effect on controlling bacterial wilt (Baptista et al., 2006). According to these same authors, during solarization, in the deeper layers of soil, temperature is only sublethal to the inoculum. Thus, microbial processes are likely to be favored by the association between temperature increase and organic matter decomposition, with greater contribution of this aspect to the control of pathogens, than only changing soil temperature (Kanaan et al., 2016). In addition, increasing soil temperature may also affect the survival of beneficial microorganisms. Therefore, under natural growing conditions, solarization should not be considered as the sole form of controlling bacterial wilt, but rather a measure capable of reducing the population of pathogens in the most superficial layers of the soil, so that the association with other measures is more effective.
Regarding the productive characteristics per plant, there was no interaction between plots and subplots. We also observed that there was no influence of treatments on the number of commercial fruits. However, the treatments applied to the soil provided a difference for the production and average mass of commercial fruits. When biofumigation was applied with poultry litter, there was an increase in these commercial characteristics both in the greenhouse and in the field (Table 3).

It can be considered that biofumigation through the application of poultry litter allowed an increase of the productive components once, in association with the fertirrigation, the availability of nutrients to the plants has increased. The use of poultry litter as organic fertilizer for tomato plants, when associated with mineral nutrition, supplies the demand for primary macronutrients (Mueller et al., 2013). It is commonly reported that poultry litter, when decomposed, improves the physical, chemical and biological characteristics of the soil, that is, increases fertility, water retention capacity, aggregation and soil porosity.

A relevant aspect is that biofumigation with chicken manure was performed four months before transplanting the seedlings. For organic fertilization to increase production, it must be applied in advance to the soil (Sediyama et al., 2014), as in this study, four months before transplanting. In other horticultural species, an increase of productivity was also observed, with the application of poultry litter, as in Arracacia xanthorrhiza (Graciano et al., 2006), Colocasia esculenta, lettuce
(Zárate et al., 2007), Allium fistulosum, Eruca sativa (Zárate et al., 2006) and carrot (Araujo et al., 2004).

The results of the control characteristics of bacterial wilt and fruit production in this work highlight the possibility of using solarization and biofumigation together. Baptista et al. (2006), when growing potato in an area infested with $R$. salanacearum, also emphasized the association between solarization and biofumigation with chicken manure as an alternative for the increment of the productive components.

Grafting, although it did not provide an increment of the productive characteristics per plant, was efficient in controlling bacterial wilt. In the field environment, grafting was more efficient than solarization and biofumigation, promoting increased sanity and reducing infection of tomato plants.

Grafting is a well-established and efficient technique in regions where there is incidence of bacterial wilt in the tomato crop (Lopes et al., 2015). The main obstacles in using this technique in Brazil relates to the need for skilled workforce and the increase in the cost to obtain the seedling (Zeist et al., 2017a). In addition, there is a shortage of rootstocks, which, together with the control of soil pathogens, provide an increase in fruit production and thus better justify its use (Zeist et al., 2017b).

Although grafting hybrid Absoluto on the 'Guardião' rootstock in field cultivation has been more efficient in controlling bacterial wilt than the solarization and biofumigation with chicken manure, it is advisable to adopt more than one control measure. Its efficacy, like that of other commercial

Table 3. Effects of solarization and biofumigation with chicken manure in soil naturally infested with Ralstonia solanacearum on production of commercial fruits (CF) and average mass of commercial fruits (AMCF) of tomato hybrid Absoluto in two commercial growing environments. Barra do Rio Azul, UNICENTRO, 2013/2014.

\begin{tabular}{lccccc}
\hline \multirow{2}{*}{ Treatments } & \multicolumn{2}{c}{ Greenhouse } & & \multicolumn{2}{c}{ Field } \\
\cline { 2 - 3 } \cline { 5 - 6 } & CF (kg/plant) & AMCF (g/fruit) & & PCF (kg/plant) & AMCF (g/fruit) \\
\hline Solarization & $6.91 \mathrm{~b}$ & $213.14 \mathrm{c}$ & & $6.30 \mathrm{~b}$ & $200.13 \mathrm{ab}$ \\
Biofumigation & $8.12 \mathrm{a}$ & $241.48 \mathrm{ab}$ & & $7.13 \mathrm{a}$ & $215.21 \mathrm{ab}$ \\
Solarization + biofumigation & $8.57 \mathrm{a}$ & $254.33 \mathrm{a}$ & & $7.28 \mathrm{a}$ & $219.78 \mathrm{a}$ \\
Control & $7.04 \mathrm{~b}$ & $219.72 \mathrm{bc}$ & & $6.04 \mathrm{~b}$ & $191.27 \mathrm{~b}$ \\
\hline CV $(\%)$ & 4.57 & 7.99 & & 6.27 & 9.61 \\
\hline
\end{tabular}

Means followed by same letters in the column do not differ significantly from each other by Tukey test, $\mathrm{p} \leq 0.05$. 
rootstocks, is isolated, dependent and unstable under conditions of high temperature and high humidity (Lopes et al., 2015; Rossato et al., 2018). Thus, the benefit of solarization associated to the addition of chicken manure is evident in controlling bacterial wilt, and the increase of the productive characteristics of hybrid Absoluto in areas infested with $R$. solanacearum in subtropical region.

\section{REFERENCES}

ARAUJO, C; ZÁRATE, NAH; CARMO VIEIRA, M. 2004. Produção e perda de massa póscolheita de cenoura 'Brasília', considerando doses de fósforo e de cama de frango semi decomposta. Acta Scientiarum. Agronomy 26: $131-138$

BAILEY, K.; LAZAROVITS, G. 2003. Suppressing soil-borne diseases with residue management and organic amendments. Soil and Tillage Research 72: 169-180.

BAPTISTA, MJ; LOPES, CA; SOUZA, RB; FURUMOTO, O. 2006. Efeito da solarização e biofumigação, durante o outono, na incidência de murcha bacteriana e produtividade da batata. Horticultura Brasileira 24: 99-102.

BAPTISTA, MJ; REIS JUNIOR, FB; XAVIER, GR; ALCÂNTARA, C; OLIVEIRA, AR; SOUZA, RB; LOPES, CA. 2007. Eficiência da solarização e biofumigação do solo no controle da murcha bacteriana do tomateiro no campo. Pesquisa Agropecuária Brasileira 42: 933-938.

CAMPBELL, CL; MADDEN, LV. 1990. Introduction to plant disease epidemiology. New York: John Wiley \& Sons, 560p.

COCA, DM; RAGASSI, CF; LOPES, CA. 2012. Utilização de esterco como medida auxiliar no controle da murcha bacteriana em genótipos de batata. Revista Latinoamericana de la Papa 17: 152-169.

FEGAN, M; PRIOR, P. 2005. How complex is the "Ralstonia solanacearum species complex"? In: ALLEN, C; PRIOR, P; HAYWARD, AC (eds). Bacterial wilt disease and the Ralstonia solanacearum species complex. St. Paul: APS Press.p.449-461.

GRACIANO, JD; ZÁRATE, NAH; VIEIRA, MC; ROSA, YBCJ; SEDIYAMA, MAN; RODRIGUES, ET. 2006. Efeito da cobertura do solo com cama-de-frango semidecomposta sobre dois clones de mandioquinha-salsa. Acta Scientiarum. Agronomy 28: 365-371.

INOUE-NAGATA, AK; LOPES, CA; REIS, A; PEREIRA, RB; QUEZADO-DUVAL, AM; PINHEIRO, JB; LIMA, MF. 2016.Doenças do tomateiro. In: AMORIM, L; REZENDE, JAM; BERGAMIM FILHO, A; CAMARGO, LEA (eds). Manual de Fitopatologia. v.2. 5. ed.Ouro Fino: Agronômica Ceres. p.697-732.

KANAAN, H; MEDINA, S; KRASSNOVSKY, A; RAVIV, M. 2015. Survival of Macrophomina phaseolina. 1. and Verticillium dahliae during solarization as affected by composts of various maturities.Crop Protection 76: 108-113.

KANAAN, H; MINZ, D; MEDINA, S; KRASNOVSKY, A; RAVIV, M. 2016. The interdependent effects of solar disinfestation and compost maturity level on soil microbial activity. Phytoparasitica 44: 55-64.

LEBEAU, A; DAUNAY, MC; FRARY, A; PALLOIX, A; WANG, JF; DINTINGER, J; CHIROLEU, F; WICKER, E; PRIOR, P. 2011. Bacterial wilt resistance in tomato, pepper, and eggplant: Genetic resources respond to diverse strains in the Ralstonia solanacearum species complex. Phytopathology 101: 155-165.

LOPES, CA; ROSSATO, M. 2013. Diagnóstico de Ralstonia solanacearum em tomateiro. Brasília: Embrapa Hortaliças. 10p. (Comunicado Técnico 92).

LOPES, CA. 2015. Bacterialwilt - a threatening disease of tomato cultivated under warm temperatures. Brasília: Embrapa Hortaliças. 4p. (Comunicado Técnico 109).

LOPES, CA; BOITEUX, LS; ESCHEMBACK, V. 2015. Eficácia relativa de porta-enxertos comerciais de tomateiro no controle da murcha bacteriana. Horticultura Brasileira 33: 125-130.

MEHTA, CM; PALNI, U; FRANKE-WHITTLE, IH; SHARMA, AK. 2014. Compost: Its role, mechanism and impact on reducing soilborne plant diseases. Waste Management 34: 607-622.

MUELLER, S; WAMSER, AF; SUZUKI, A; BECKER, WF. 2013. Produtividade de tomate sob adubação orgânica e complementação com adubos minerais. Horticultura Brasileira 31: 86-92.

OZ, H; COSKAN, A; ATILGAN, AJ. 2017. Determination of effects of various plastic covers and biofumigation on soil temperature and soil nitrogen form in greenhouse solarization: new solarization cover material. Journal of Polymers and the Environment 25: 370-377.

PLANK, JE.1963. Plant disease: epidemic and control. New York: Academic Press, 349p.
ROSSATO, M; LOPES, CA; BOITEUX, LS. 2018. Evaluation of Solanum peruvianum (sensu lato) germplasm to a standard Ralstonia solanacearum race 1/biovar 1 isolate and to a novel 'Hawaii 7996' resistance-overcoming race 3/biovar 2A isolate from Brazil. Tropical Plant Pathology 43: 477-483.

SEDIYAMA, MAN; SANTOS, IC; LIMA, PC. 2014. Cultivo de hortaliças no sistema orgânico. Revista Ceres 61: 829-837.

SILVA, VB; SILVA, AP; DIAS, BO; ARAUJO, JL; SANTOS, D; FRANCO, RP. 2014. Decomposition and mineralization of $\mathrm{N}, \mathrm{P}$ and $\mathrm{K}$ of cattle manure and poultry litter isolated or mixed. Revista Brasileira de Ciência do Solo 38: 1537-1546.

SILVA, FAS; AZEVEDO, CAV. 2016.The assistat software version 7.7 and its use in the analysis of experimental data.African Journal of Agricultural Research 11: 3733-3740.

TRANI, PE; TIVELLI, SW; CARRIJO, OA. 2011. Fertirrigação em hortaliças. 2. ${ }^{\mathrm{a}}$ ed. Campinas: Instituto Agronômico, Série Tecnologia APTA(Boletim Técnico IAC, 196). 53p.

WREGE, MS; STEINMETZ, S; REISSER JUNIOR, C; ALMEIDA, IR. 2011. Atlas climático da região sul do Brasil: estados do Paraná, Santa Catarina e Rio Grande do Sul. 1. Pelotas: Embrapa Clima Temperado; Embrapa Florestas, 336p.

YULIAR, YAN; TOYOTA, K. 2015. Recent trends in control methods for bacterial wilt diseases caused by Ralstonia solanacearum. Microbes and environments 30: 1-11.

ZÁRATE, NAH; VIEIRA, MC; GRACIANO, JD; GASSI, RP; ONO, FB; AMADORI, AH. 2006. Produção de cebolinha, solteira e consorciada com rúcula, com e sem cobertura do solo com cama-de-frango. Semina: Ciências Agrárias 27: 505-514.

ZÁRATE, NAH; VIEIRA, MC; GIULIANI, AR; HELMICH, M; PONTIM, BCÁ; PEZZONI FILHO, JC. 2007. Produção e renda de taro Macaquinho, solteiro e consorciado com alface 'Salad Bowl', em solo com cobertura de camade-frango semidecomposta. Semina: Ciências Agrárias 28: 563-570.

ZEIST, AR; RESENDE, JTV; GIACOBBO, CL; FARIA, CMDR; DIAS, DM. 2017a.Graft takes of tomato on other solanaceous plants. Revista Caatinga 30: 513-520.

ZEIST, AR; RESENDE, JTV; SILVA, IFL; OLIVEIRA, JRF; FARIA, CMDR; GIACOBBO, CL. 2017b. Characteristics of tomato plant cultivar Santa Cruz Kada grafted on species of the genus Solanum. Horticultura Brasileira 35: 419-424. 